Wewarah: Jurnal Pendidikan Multidisipliner

Volume 1 (1) 24 - 35 Januari 2022

The article is published with Open Access at http://e-journal.unipma.ac.id/index.php/WEWARAH

\title{
Implementasi Gerakan Literasi Sekolah (GLS) Untuk Menumbuhkan Minat Baca Siswa di Masa Pandemi Covid-19 pada Siswa Kelas V SDN Rejomulyo 1
}

\author{
Agus Mustofa $\bowtie$, Universitas PGRI Madiun \\ Parji, Universitas PGRI Madiun \\ Dwi Rohman Soleh, Universitas PGRI Madiun \\ masmuzt44@gmail.com
}

\begin{abstract}
Abstrak: Tujuan penelitian ini adalah (1) Mendeskripsikan dan menjelaskan Implementasi Gerakan Literasi Sekolah (GLS) untuk menumbuhkan minat baca siswa di masa pandemi covid-19 pada siswa kelas V SDN Rejomulyo 1. (2) Mendeskripsikan dan menjelaskan kendala yang dihadapi dalam Implementasi Gerakan Literasi Sekolah (GLS) untuk menumbuhkan minat baca siswa di masa pandemi covid-19 pada siswa kelas V SDN Rejomulyo 1. (3) Mendeskripsikan dan menjelaskan faktor-faktor yang mendukung Implementasi Gerakan Literasi Sekolah (GLS) untuk menumbuhkan minat baca siswa di masa pandemi covid-19 pada siswa kelas V SDN Rejomulyo 1. Penelitian ini dilakukan di SD Negeri Rejomulyo 1 menggunakan pendekatan penelitian kualitatif dengan jenis penelitian kualitatif deskriptif. Data dikumpulkan dengan menggunakan metode observasi, wawancara, dan dokumentasi. Data yang terkumpul berupa kata-kata dianalisis dengan reduksi, penyajian data, dan penarikan kesimpulan.
\end{abstract}

Keywords: Implementation, School Literacy Movement, Reading Interest

Abstract: The aims of this study are (1) to describe and explain the implementation of the school literacy movement (GLS) to foster student interest in reading during the covid-19 pandemic in fifth grade students at SDN Rejomulyo 1. (2) to describe and explain the obstacles faced in the implementation of the school literacy movement. (GLS) to foster student interest in reading during the covid-19 pandemic in fifth grade SDN Rejomulyo 1. (3) Describe and explain the factors that support the Implementation of the School Literacy Movement (GLS) to foster student interest in reading during the COVID-19 pandemic. 19 for the fifth grade's students of SDN Rejomulyo 1. This research was conducted at SD Negeri Rejomulyo 1 using a qualitative research approach with descriptive qualitative research. Data were collected using the methods of observation, interviews, and documentation. The data collected in the form of words were analyzed by reduction, data presentation, and drawing conclusions.

Kata kunci: Implementasi, Gerakan Literasi Sekolah, Minat Baca

Citation: Mustofa, A., Parji, P., \& Soleh, D.R. (2022). Implementasi Gerakan Literasi Sekolah (GLS) Untuk Menumbuhkan Minat Baca Siswa di Masa Pandemi Covid-19 pada Siswa Kelas V SDN Rejomulyo 1. Wewarah: Jurnal Pendidikan Multidisipliner, 1(1), 24 - 35.

\section{(cc) Br}

Published by Program Pascasarjana Universitas PGRI Madiun. This work is licensed under the Creative Commons Attribution-NonCommercialShareAlike 4.0 International License. 


\section{PENDAHULUAN}

Zaman modern ini standar keberhasilan ditentukan dan dipengaruhi oleh kemampuan literasi. Literasi mulai dimaknai sebagai kunci kemajuan sebuah negara. Sejalan dengan fungsi dan tujuan pendidikan nasional di mana kemampuan literasi dapat dimaknai sebagai cara untuk mentransformasi pengetahuan serta akhlak manusia itu sendiri (Rahmawati, 2007).

Kesadaran literasi sangat dibutuhkan saat ini, terutama dalam menghadapi situasi yang mengancam manusia selama pandemi Covid-19. Kurangnya literasi masyarakat Indonesia dapat menyebabkan terhambatnya program pemerintah dalam penanganan Covid-19. Hal ini dibuktikan dengan adanya masyarakat yang acuh tak acuh dengan keadaan sekitar, seperti halnya tidak memakai masker, jaga jarak dan rajin cuci tangan untuk mencegah terjangkitnya Covid-19.

Data lain terkait minimnya kesadaran literasi di Indonesia dibuktikan dengan adanya hasil studi Program for International Student Assesment (PISA) yang diselenggarakan tiap tiga tahun sekali. Program tersebut bertujuan untuk mengukur kualitas hasil pendidikan dari berbagai negara telah dirilis pada 2018 lalu. Hasilnya menunjukkan kemampuan membaca anak Indonesia adalah yang terendah dari kemampuan bidang matematika dan sains. Nilai kemampuan membaca menunjukkan skor 371 (tiga ratus tujuh puluh satu), tertinggal 116 poin dari rata-rata Negara lain yaitu skor 487 (empat ratus delapan puluh tujuh). Melihat kenyataan dari hasil skor tersebut dapat disimpulkan bahwa kemampuan membaca seharusnya mendapat perhatian lebih. Pemerintah bersama-sama melakukan program peningkatan kemampuan membaca yang didukung oleh setiap lapisan masyarakat (Antasari, 2017).

Literasi dalam Kamus Besar Bahasa Indonesia (KBBI) diartikan sebagai kemampuan menulis dan membaca; kemampuan individu dalam mengolah informasi dan pengetahuan kecakapan hidup. Saat ini kita memasuki abad ke-21 yang menuntut siswa untuk banyak membaca dan menulis (literasi). Kegiatan membaca dan menulis diyakini akan meningkatkan keterampilan siswa dalam berpikir dan bertindak

Kemampuan Literasi merupakan kemampuan berpikir, memproses informasi dan membaca situasi yang diaplikasikan sesuai disiplin ilmu. Bukan sekedar membaca dan mengeja, tetapi membaca yang diartikan dengan mampu menganalisa, mengaktifkan penalaran dan memecahkan masalah secara kompleks. Hal ini diperlukan pembiasaan kegiatan literasi untuk menciptakan budaya literasi yang utuh.

Literasi adalah potensi yang dapat dikembangkan secara optimal sejak dini dan bukan bawaan lahir. Maka perlu adanya langkah-langkah untuk mendukung budaya literasi sejak dini. Pertama, pembiasaan aktivitas literasi dilingkup keluarga, sebagai orangtua harus menjadi contoh bagi anaknya untuk mencintai aktivitas literasi.

Membaca sebagai suatu kegiatan kognitif untuk mengembangkan pola pikir setiap manusia saat ini hingga masa mendatang dengan menemukan berbagai macam informasi dari buku yang dibaca (Naelasari, 2020). Jadi tidak dapat dipungkiri bahwa pada setiap kegiatan pembelajaran membaca merupakan kegiatan yang efektif dan merupakan suatu bagian penting dalam pembelajaran karena kita mendapatkan sebagian ilmu pengetahuan dengan membaca buku.

Dalam rangka meningkatkan minat dan daya baca siswa, Kemendikbud meluncuran Gerakan Literasi Sekolah (GLS) melalui sebuah slogan "Bahasa Penumbuh Budi Pekerti" sejak tahun 2015, Gerakan Literasi Sekolah kemudian dikembangkan berdasarkan Permendikbud Nomor 23 Tahun 2015 tentang Penumbuhan Budi Pekerti. GLS dilatarbelakangi oleh masih rendahnya budaya baca masyarakat Indonesia khususnya pelajar. Organisasi Pendidikan, Ilmu Pengetahuan, dan Kebudayaan Perserikatan Bangsa-Bangsa (UNESCO 2012) mencatat indeks minat baca di Indonesia baru mencapai 0,001. Bentuk kegiatan literasi sekolah antara lain; pembiasaan membaca buku nonteks selama 15 menit sebelum kegiatan pembelajaran dimulai, baik membaca senyap maupun nyaring, baik terbimbing atau pun mandiri. Kemudian ada membaca secara massal yang biasanya dilakukan di halaman sekolah, pembuatan jurnal atau laporan bacaan, pembuatan pohon literasi, pemanfaatan majalah dinding (mading), pemanfaatan perpustakaan sekolah, dan sebagainya. Bahkan untuk memotivasi sekolah melaksanakan GLS, diadakan berbagai lomba atau penghargaan terkait literasi bagi siswa dan guru penggerak literasi (Wiedarti, 2016).

Menumbuhkan minat membaca pada siswa memang sangat penting, karena dengan adanya minat membaca pada akhirnya siswa akan terbiasa membaca buku-buku dan jika sehari mereka tidak membaca 1 
bukupun mereka akan merasa ada yang kurang atau mereka akan merasa telah merugikan diri sendiri karena telah meninggalkan kegiatan membaca, dengan seperti itu siswa akan memiliki rasa cinta membaca.

Program literasi sekolah ini merupakan suatu usaha atau kegiatan yang bersifat partisipatif dengan melibatkan warga sekolah, baik itu guru maupun siswa. Dimana tujuan dari pelaksanaan program gerakan literasi ini adalah untuk meningkatkan kemampuan pada siswa dalam hal membaca. Sementara itu dalam sebuah pembelajaran, kegiatan membaca sangatlah dibutuhkan agar siswa lebih mudah untuk memahami materi yang ada dalam pembelajaran, salah satunya yaitu dalam pembelajaran Bahasa Indonesia (Soleh, 2020).

Gerakan literasi di SDN Rejomulyo 1 Kecamatan Karangjati telah lama diterapkan. Pihak sekolah beranggapan bahwa kegiatan membaca itu sangat penting bagi siswa yang ada di sekolah tersebut, maka dari itu perkembangan demi perkembangan pun telah dialami oleh sekolah tersebut (Yunus, 2017). Diantaranya penggunaan perpustakaan ramah anak sebagai media untuk menerapkan Gerakan Literasi Sekolah, pembuatan sudut baca, pembiasaan membaca 15 menit sebelum pelajaran, dan lain sebagainya.

Covid-19 telah memberikan perubahan yang sangat besar terhadap kegiatan belajar mengajar. Di seluruh dunia, lebih dari 1 miliar pelajar baik di usia sekolah maupun perguruan tinggi, telah didorong untuk melakukan perubahan secara radikal pada implementasi teknologi pendidikan dalam waktu sekejap. Institusi Pendidikan harus tergupuh-gupuh untuk mendesain ulang kegiatan pembelajaran bagi semua usia dari rumah. Sisi baiknya, Tekanan yang didapatkan baik secara individual, organisasi maupun masyarakat secara umum dalam menghadapi pandemi dan krisis kali ini justru dapat mempercepat proses perwujudan masyarakat industri 4.0 (Suwandi, 2019).

Proses belajar mandiri pada anak usia dini dan sekolah dasar menjadi yang paling rentan terhadap kehilangan kesempatan belajar yang efektif. Di usia sekolah dasar, siswa diharapkan dapat membangun lingkungan dan keterampilan berpikir struktural. Hal ini memerlukan pendampingan ekstra dikarenakan anak-anak di usia ini mudah terdistraksi dan kehilangan konsentrasi belajarnya (Soleh, 2016). Oleh karenanya, peranan guru tetap sangat penting, disamping usaha dari para orang tua yang tentu saja mau tidak mau harus beradaptasi untuk meningkatkan kapasitas diri mereka dalam mendampingi buah hati guna hasil terbaik di masa depannya.

Dalam kegiatan literasi di SDN Rejomulyo 1 pada masa pandemi berbagai persoalan pun muncul dalam hal sumber bacaan. Bahan bacaan siswa menjadi terbatas karena tidak bisa mengakses perpustakaan sekolah selama pandemi. Selain itu siswa juga akan mengalami kesulitan dalam membaca walaupun sebenarnya ini adalah waktu yang tepat untuk memperbanyak membaca karena banyaknya waktu luang yang dimiliki. Tingkat kecemasan yang berlebih menjadikan alam bawah sadar sulit untuk fokus. Hal ini yang menyebabkan siswa cenderung untuk memilih menikmati hiburan dan kegiatan lainnya dibandingkan menghabiskan waktu untuk membaca. Persoalan lainnya lainnya yaitu tidak ada teman diskusi. Teman diskusi dalam kegiatan literasi penting, dan siswa lebih suka berdiksusi dengan teman sebaya ketimbang anggota keluarga. Alternatif kegiatan yang bisa dilakukan yakni memanfaatkan buku-buku digital. Namun, tidak semua siswa memiliki gawai dan kuota internet untuk mengakses buku-buku digital.

Dengan adanya latar belakang di atas, peneliti menyusun penelitian dengan judul "Implementasi Gerakan Literasi Sekolah (GLS) Untuk Menumbuhkan Minat Baca Siswa di Masa Pandemi Covid-19 pada Siswa Kelas V SDN Rejomulyo 1.

\section{METODE}

Peneliti menggunakan jenis penelitian kualitatif untuk mendeskripsikan hasil dari penelitian secara tertulis berdasarkan hasil dari wawancara, ataupun dari sesuatu yang diamati oleh peneliti ketika berada di lapangan. Penelitian kualitatif adalah penelitian yang dihasilkan berdasarkan penelitian tentang fenomena yang dihadapi oleh peneliti secara langsung di tempat penelitian (Moleong, 2009).

Disesuaikan dengan tujuan pokok penelitian yang dilakukan, maka peneliti menggunakan jenis pendekatan deskriptif kualitatif untuk mendeskripsikan tentang implementasi gerakan literasi sekolah untuk menumbuhkan minat membaca siswa kelas V di SDN Rejomulyo 1. 
Penelitian ini dilakukan di SDN Rejomulyo 1 Kecamatan Karangjati, Ngawi. Adapun waktu penelitian ini dilaksanakan pada semester ganjil tahun ajaran 2021/2022. Penentuan waktu penelitian mempertimbangkan fokus penelitian dan kemampuan peneliti dalam mengumpulkan data dimana pada semester itu masih dalam suasana pandemi Covid-19 sehingga kegiatan belajar mengajar di SDN Rejomulyo 1 belum berjalan normal namun sudah dilaksanakan pembelajaran tatap muka secara terbatas.

\section{HASIL PENELITIAN}

\section{Implementasi Gerakan Literasi Sekolah di SDN Rejomulyo 1}

Berdasarkan data yang diperoleh, penerapan gerakan literasi sekolah di SDN Rejomulyo 1 diterapkan sejak dicanangkannya peraturan menteri pendidikan dan kebudayaan nomor 23 tahun 2015 tentang penumbuhan budi pekerti yang merupakan pintu masuk bagi program Gerakan Literasi Sekolah. Pengertian literasi sekolah dalam konteks GLS adalah kemampuan mengakses, memahami, dan menggunakan sesuatu secara cerdas melalui berbagai aktivitas, antara lain membaca, melihat, menyimak, menulis, dan atau berbicara. Terkait dengan kegiatan pembelajaran, aktivitas tersebut masuk dalam pembelajaran saintifik, yang mana SDN Rejomulyo 1 telah menerapkan kurikulum 2013. Aktivitas membaca, menulis, menyimak, dan berbicara merupakan keterampilan yang harus dikuasai siswa, sehingga dalam pembelajaran saintifik kemampuan literasi siswa perlu dilatih sebagai faktor keberhasilan dalam memperoleh informasi yang luas dari berbagai sumber. Literasi sekolah bertujuan untuk memberikan pembiasaan dan pengembangan siswa agar gemar membaca dan menciptakan lingkungan sekolah yang literat. Tujuan literasi terbagi menjadi tujuan umum dan tujuan khusus yang dijadikan tujuan gerakan literasi sekolah di SDN Rejomulyo 1 berdasarkan apa yang telah disampaikan oleh Kepala Sekolah, yaitu :

a. Tujuan Umum

Menumbuhkembangkan budi pekerti peserta didik melalui pembudayaan ekosistem literasi sekolah yang diwujudkan dalam gerakan literasi sekolah agar mereka menjadi pembelajar sepanjang hayat.

b. Tujuan Khusus

1) Menumbuhkembangkan budaya literasi di sekolah.

2) Meningkatkan kapasitas warga dan lingkungan sekolah agar literat.

3) Menjadikan sekolah sebagai taman belajar yang menyenangkan dan ramah anak agar warga sekolah mampu mengelola pengetahuan.

4) Menjaga keberlanjutan pembelajaran dengan menghadirkan beragam buku bacaan.

Hal tersebut menurut Kepala SDN Rejomulyo 1 diterapkan sesuai dengan paduan gerakan literasi sekolah yang telah dibuat oleh Kementerian Pendidikan dan Kebudayaan Direktorat Jenderal Pendidikan Dasar dan Menengah. Sesuai dengan yang tercantum pada buku panduan tersebut, bahwa agar orangtua berpartisipasi dalam gerakan literasi sekolah, maka pihak sekolah harus mempunyai kiat-kiat sebagai berikut :

a. Mendengarkan aspirasi dari orangtua siswa.

Setiap ada orangtua siswa yang mempunyai usulan ataupun rekomendasi suatu kegiatan yang bersangkutan dengan program gerakan literasi sekolah ataupun yang lainnya, pihak sekolah selalu menerimaaspirasi tersebut yang kemudian dibicarakan lagi oleh Kepala Sekolah bersama dengan guru yang lainnya. Umumnya aspirasi dari orangtua siswa berkaitan dengan kegiatan menghias pojok kelas sebagus mungkin dan kemudian diberikan nilai dan dipilih satu kelas yang akan mendapatkan penghargaan.

b. Komunikasi dengan orang tua siswa

Pihak sekolah berusaha semaksimal mungkin untuk dapat menjalin komunikasi dengan orangtua siswa melalui nomer kontak sekolah yang dibagikan kepada mereka sehingga sewaktu-waktu orangtua siswa dapat menghubungi pihak sekolah apabila ada pertanyaan atau masukan terkait Gerakan Literasi Sekolah.

c. Penyesuaian Jadwal

Saat hendak mengadakan kegiatan dalam programgerakan literasi sekolah yang melibatkan orangtua siswa, sebelumnya pihak sekolah juga akan menyesuaikan jadwal kegiatan dengan kesibukan dari 
masing-masing orangtua siswa serta bagaimana kondisi sosial ekonomi orangtua siswa saat itu, sehingga saat kegiatan tersebut berlangsung tidak terdapat perselisihan antar pihak sekolah dengan orangtua siswa. Semuanyabisa melaksanakan kegiatan tersebut dengan ikhlas layaknya melaksanakan kegiatan dengan keluarga sendiri.

\section{Minat Baca Siswa Setelah Diterapkan Gerakan Literasi Sekolah di SDN Rejomulyo 1}

Membaca merupakan jantung pendidikan. Dalam hal ini, orang yang sering membaca, pendidikannya akan maju dan ia akan memiliki wawasan yang luas. Tentu saja hasil membacanya itu akan menjadi pengetahuan dan pengalaman yang dimiliki seseorang. Jadi, semakin sering seseorang mmebaca, maka semakin maju pulalah pendidikannya. Hal nilah yang melatarbelakangi banyak orang yang mengatakan bahwa membaca sama dengan membuka jendela dunia. Dengan membaca kita dapat mengetahui seisi dunia dan pola berpikir kita pun akan berkembang. Di sekolah, pembelajaran membaca perlu difokuskan pada aspek kemmapuan memahami isi bacaan. Oleh sebab itu, siswa perlu dilatih secara intensif untuk memahami sebuah teks bacaan. Hal ini berarti siswa bukan menghafal isi bacaan tersebut, melainkan memahami isi bacaan.

Pihak SDN Rejomulyo 1 ingin mewujudkan apa yang seharusnya didapatkan siswa dari sekolah selain berbagai macam pelajaran yang mereka pelajari, siswa juga harus mendapatkan bekal ilmu pengetahuan sebanyak- banyaknya untuk kehidupan yang akan datang dengan cara membaca berbagai macam buku, membiasakan siswa dengan kegiatan membaca buku baik buku pelajaran ataupun nonpelajaran tanpa kita mengatur siswa buku apa yang ingin mereka baca, karena pada dasarnya tiap siswa memiliki ketertarikan sendiri pada buku-buku yang mereka pilih untuk dibaca.Oleh karena itu SDN Rejomulyo 1 menerapkan program gerakan literasi sekolah sesuai dengan peraturan menteri pendidikan dan kebudayaan Nomor 23 tahun 2015 guna menumbuhkan minat baca siswa.

Selanjutnya, sekolah menerapkan kiat-kiat guna mewujudkan lingkungan sekolah yang literat, diantaranya :

a. Lingkungan Fisik

1) Di lingkungan sekolah terdapat pajangan hasil karya siswa yang bisa dibaca ulang ataupun dilihat ulang oleh seluruh warga sekolah. Sekalipun bukan hasil karya siswa, pajangan yang terpampang di sepanjang lingkungan sekolah merupakan hasil buatan tim pelaksana gerakan literasi sekolah. Tujuannya supaya ketika siswa berjalan menyusuri ruang sekolah, siswa dapat membaca tulisantulisan yang terpampang di sepanjang jalan yang di lewati.

2) Pada setiap kegiatan gerakan literasi sekolah, terkadang siswa disuruh membuat sebuah karya berupa gambar ataupun tulisan. Hasil dari siswa membuat karya tersebut kemudian dipasang di tempat pajangan karya siswa.

3) Pihak sekolah menyediakan buku dan berbagai macam materi bacaan lain yang tersedia di sudut baca semua ruang kelas. Buku-buku yang berada di sudut baca semua ruang pojok kelas tersebut setiap minggunya bahkan bisa juga setiap hari mengalami perubahan sesuai dengan permintaan siswa, jika ada siswa yang ingin buku-buku di pojok baca segera diperbarui, maka mau tidak mau guru harus melakukan hal tersebut menunjukkan bahwa sangat antusiasnya siswa pada kegaitan literasi yang diterapkan oleh sekolah dan siswa tidak akan merasa jenuh dengan buku bacaan yang disediakan oleh guru.

4) Buku-buku bacaan ataupun materi bacaan lain tidak hanya tersedia di pojok baca siswa ataupun perpustakaan sekolah, namun buku-buku tersebut dengan tema yang berbeda-beda juga berada di ruangan lainnya, seperti di ruang guru, ruang kepala sekolah, ruang tamu.

b. Lingkungan Akademik

1) Pihak sekolah menyediakan waktu yang cukup untuk melaksanakan kegiatan gerakan lietrasi sekolah supaya dapat terwujud pembiasaan literasi yang lebih baik. Waktu yang disediakan tersebut biasanya disusun dalam jadwal kunjungan ke perpustakaan untuk seluruh kelas mulai dari kelas 1 sampai kelas 6. Kegiatan tersebut ada yang dilaksanakan tiap minggu, tiap bulan, bahkan tiap tahun dan tema kegiatannya berbeda-beda menyesuaikan dengan tingkatan kelas. 
2) Dengan adanya jadwal khusus kegiatan program gerakan literasi sekolah yang telah dibuatkan oleh pihak sekolah, diharapkan waktu berkegiatan literasi agar tidak terbuang untuk kepentingan lain dan dapat dilaksanakan secara konsisten.

3) Pihak sekolah melakukan evaluasi ataupun pengembangan terkait dengan gerakan literasi sekolah yang telah diterapkan. Mengevaluasi apa yang dirasa kurang yang kemudian dapat diperbaiki dan dikembangkan lagi supaya ada peningkatan.

4) Melihat dari banyaknya minat baca siswa pada buku fiksi dan non fiksi, maka pihak sekolah lebih memperbanyak penyediaan kedua jenis buku tersebut.

5) Ada buku wajib baca untuk warga sekolah. Seperti halnya selama pembelajaran jarak jauh ini, siswa diwajibkan membaca buku yang telah disediakan oleh guru. Guru telah merancang buku yang dibuat menyesuaikan dengan tingkatan kelas siswa, kemudian guru mengirimkannya kepada siswa melalui pesan whatsapp dan siswa dapat membacanya. Buku tersebut merupakan pengganti sementara bukubuku yang ada di perpustakaan selama pelaksanaan pembelajaran jarak jauh.

\section{Dampak Implementasi Gerakan Literasi bagi Sekolah}

Berdasarkan hasil wawancara peneliti kepada kepala sekolah terkait dengan dampak dari diterapkannya program gerakan literasi sekolah di SDN Rejomulyo 1 dan khususnya di kelas V, bahwa beliau menyatakan dampak tersebut dapat dilihat dengan adanya siswa yang lebih sering berkunjung dan beraktivitas di perpustakaan sekolah. Hal tersebut telah menunjukkan bahwa terjadi peningkatan minat baca siswa. Adapun beberapa dampak dari implementasi gerakan literasi sekolah di SDN Rejomulyo 1 diantaranya sebagai berikut.

a. Infrastruktur Bertambah

Dengan diterapkannya gerakan literasi sekolah di SDN Rejomulyo 1, akhirnya pihak sekolah tidak hanya memperbaiki perpustakaan sekolah saja, namun juga memperbaiki seluruh fasilitas sekolah sesuai dengan target literasi sekolah yang ingin dicapai. Kemudian penambahan tulisan-tulisan baik tulisan angka ataupun kata-kata mutiara di bagian-bagian kelas sesuai dengan apa yang disampaikan oleh Kepala Sekolah saat melakukan wawancara dengan peneliti.

\section{b. Support Stage Holder}

Stage holder disini bukan hanya tim pelaksana gerakan literasi sekolah namun juga dari wali murid yang juga turut andil dalam pelaksanaan program gerakan literasi sekolah. Meskipun tidak dalam seluruh kegiatan namun ada beberapa kegiatan yang melibatkan wali siswa, diantaranya: wali siswa ikut andil dalam penghiasan pojok baca tiap kelas, dan juga wali siswa biasanya ikut andil dalam kegiatan membaca nyaring yang diadakan oleh pihak sekolah. Dengan seperti itu, wali siswa juga akan terbiasa mengajak anak-anaknya untuk lebih rutin membaca buku ketika anak sedang bersama orangtua. Karena pada dasarnya pendidikan pertama bagi siswa adalah orangtua mereka.

\section{c. Pola Pikir Berliterasi}

Sebelum diterapkannya gerakan literasi sekolah di SDN Rejomulyo 1, Kepala Sekolah berusaha untuk bisa menyamakan pola pikir berliterasi terlebih dahulu, yaitu antar guru kemudian dibawa kepada siswa dan selanjutnya ke seluruh anggota yang ada di sekolah tersebut termasuk juga wali siswa yang meskipun mereka tidak setiap haru dan setiap waktu berada di sekolah tersebut, namun setidaknya pihak sekolah dapat menyamakan pola pikir (mindset) berliterasi kepada semua anggota sekolah, supaya dalam pelaksanaan program literasi sekolah ini bukan hanya guru atupun siswa saja yang mengetahui dan terbiasa dengan adanya kegiatan literasi tersebut, namun orangtua siswa juga dapat mengetahuinya.

d. Lingkungan Sosial dan Afektif

1) Penghargaan terhadap prestasi peserta didik

Setelah diterapkannya gerakan lietarsi sekolah banyak siswa yang mengikuti berbagai macam lomba yang berkaitan dengan literasi dan kebanyakan dari mereka mendapatkan juara. Siswa yang telah memenangkan lomba diberikan apresiasi oleh pihak sekolah dengan diberikannya hadiah kepada siswa

2) Kepala Sekolah terlibat aktif dalam pengembangan literasi. 
Bukan hanya guru atau tim pelaksana gerakan literasi sekolah yang terlibat dalam pengembangan literasi namun Kepala Sekolah juga terlibat aktif didalamnya. Setiap bulannya kepala sekolah melaksanakan evaluasi bersama semua guru terutama guru kelas dan tim pelaksana program gerakan literasi sekolah. Pelaksanaan evaluasi tiap bulan berguna untuk mengetahui kekurangan dan kelebihan, memperbaiki dan mengembangkan program yang telah diterapkan di sekolah, dengan seperti itu program literasi mengalami perbaikan dan kemajuan di tiap tahunnya.

3) Tenaga kependidikan dilibatkan dalam proses pengambilan keputusan.

Saat evaluasi ataupun rapat membahas tentang program kegiatan gerakan literasi sekolah yang akan dilaksanakan, pihak sekolah juga melibatkan tenaga kependidikan dan bukan guru ataupun kepala sekolah saja yang diajak untuk membahas demi kemajuan dan perbaikan program gerakan literasi sekolah ini, tenaga kependidikan juga berhak untuk mengemukakan pendapatnya dan berhak juga untuk memutuskan sesuatu yang telah disetujui oleh banyak pihak yang berada dalam rapat.

\section{Dampak Implementasi Gerakan Literasi bagi Kelas V}

Literasi bukan hanya aktivitas membaca dan menulis saja, akan tetapi juga kegiatan dalam menganalisa informasi yang telah dibacanya. Dampak literasi bagi siswa kelas V SDN Rejomulyo 1 berdasarkan wawancara dengan guru dan siswa juga hasil penelitian di kelas diantaranya:

a. Meningkatnya nilai mata pelajaran khususnya pelajaran Bahasa Indonesia.

b. Menambah kosakata siswa dalam berbahasa.

c. Menambah wawasan dan informasi baru.

d. Meningkatnya kemampuan siswa dalam menulis dan merangkai kata-kata.

e. Menumbuhkan kreatifitas siswa dalam berpikir dan menganalisa

Selain itu, literasi juga membawa dampak yang baik bagi kesehatan siswa antara lain mengurangi stres, meningkatkan semangat belajar, dan meningkatkan kebiasaan positif.

\section{PEMBAHASAN}

Sebagaimana telah kita ketahui pada bab sebelumnya bahwa, yang melandasi Implementasi Gerakan Literasi Sekolah di SDN Rejomulyo 1 adalah adanya penurunan minat baca siswa ataupun kegiatan literasi yang lain seperti mendengarkan, bercerita, juga mempelajari ilmu pengetahuan yang lainnya. Oleh sebab itu, pihak sekolah berinisiatif untuk menerapkan gerakan literasi sekolah di SDN Rejomulyo 1 dengan dukungan dari berbagai pihak.

Selama penerapan program gerakan literasi sekolah di SDN Rejomulyo 1 ini, pihak sekolah memiliki beberapa strategi awal yang dilakukan, sebelum hingga mereka bisa sukses menerapkan program tersebut hingga saat ini. Berikut beberapa strategi awal yang dilakukan oleh Kepala Sekolah dibantu oleh guru dan warga sekolah yang lain:

1. Mendekatkan fasilitas yang berhubungan dengan literasi kepada siswa, misalnya mendekatkan bukubuku dari perpustakaan kepada siswa melalui pojok baca di masing-masing kelas.

2. Melakukan perbaikan isi perpustakaan serta tatanan isi perpustakaan supaya lebih nyaman jika siswa berada dalam perpustakaan.

3. Memperbarui buku-buku yang ada dalam perpustakaan sekolah. Buku-buku yang sudah sering dibaca ataupun yang tahun terbitannya sudah cukup lama, diganti dengan buku baru yang lebih layak untuk dibaca oleh siswa tingkat sekolah dasar.

4. Buku-buku yang ada di perpustakaan sekolah tempatnya dibedakan sesuai dengan jenis buku sehingga mempermudah siswa untuk mencari buku yang mereka inginkan.

5. Membuatkan jadwal kunjungan wajib ke perpustakaan sekolah pada tiap kelas. Namun siswa juga diperbolehkan mengunjungi perpustakaan di lain waktu wajib kunjungan saat jam istirahat.

6. Adanya penjaga perpustakaan yang bertugas memerintahkan siswa mengisi daftar hadir berkunjung ke perpustakaan yang setiap minggunya dilakukan rekapitulasi untuk mengetahui apakah pengunjung 
perpustakaan setiap harinya meningkat ataukah semakin menurun. Menurun dan meningkatnya minat baca siswa salah satunya dapat diketahui dari daftar hadir perpustakaan.

Peraturan Menteri Pendidikan dan Kebudayaan Nomor 23 Tahun 2015 tentang penumbuhan budi pekerti, salah satunya mengenai kegiatan membaca buku nonpelajaran selama 15 menit sebelum waktu belajar dimulai. Kegiatan tersebut adalah upaya menumbuhkan kecintaan membaca kepada peserta didik dan pengalaman belajar yang menyenangkan sekaligus merangsang imajinasi siswa.

Sarana literasi mencakup perpustakaan sekolah, sudut baca kelas, dan area baca. Perpustakaan berfungsi sebagai pusat pembelajaran di SD. Pengembangan dan penataan perpustakaan menjadi bagian penting dari pelaksanaan gerakan literasi sekolah di Sekolah Dasar dan pengelolaam pengetahuan yang berbasis pada bacaan. Perpustakaan yang dikelola dengan baik mampu meningkatkan minat baca warga. Perpustakaan SD idealnya berperan dalam mengkoordinasi pengelolaan sudut baca kelas, area baca, dan prasarana literasi lain di SD tersebut.

Di kelas V SDN Rejomulyo 1 selain melalui kunjungan perpustakaan yang menjadi sarana literasi, Implementasi Gerakan Literasi Sekolah dilakukan melalui pengembangan sudut baca kelas yang antara lain sebagai berikut:

1. Menyediakan buku-buku fiksi dan nonfiksi untuk dibaca pada kegiatan 15 menit membaca sebelum pelajaran dimuali di setiap harinya.

2. Bacaan yang disediakan sesuai dengan jenjang kemampuan membaca siswa kelas V.

3. Dihiasi oleh poster kampanye membaca dan bahan kaya teks lainnya.

4. Dikelola oleh guru, orang tua, dan siswa secara bergantian.

5. Diperkaya dengan buku-buku yang dibawa siswa.

6. Buku bacaan koleksi perpustakaan dirotasi secara bergilir sesuai tingkatan kelas.

7. Aman dan menyenangkan dengan hiasan yang dibuat oleh siswa bersama orang tua.

Selama masa pandemi Covid-19 praktis kegiatan belajar mengajar harus dilaksanakan secara daring. Oleh karena itu kegiatan literasi yang berhubungan dengan kelas dan perpustakaan tidak dapat berjalan seperti biasanya. Namun demikian sekolah membuat kebijakan untuk memberikan bacaan kepada siswa yang berupa file atau e-book yang dapat diakses oleh siswa secara online. Selain itu sekolah meminjamkan buku-buku dari perpustakaan kepada siswa yang dikembalikan dalam waktu yang disepakati, namun hal ini tentunya harus melalui protokol kesehatan yang ketat.

Pertengahan semester ganjil tahun pelajaran 2021/2022 di saat penelitian ini dilaksanakan, pemerintah telah meluncurkan kebijakan pelaksanaan pembelajaran tatap muka terbatas. Sehingga kegiatan literasi di kelas $\mathrm{V}$ juga mulai dapat dilaksanakan lagi meskipun masih melalui protokol kesehatan seperti:

1. Pengecekan suhu tubuh pada saat siswa datang ke sekolahan.

2. Cuci tangan dengan sabun dan air mengalir yang disediakan di depan kelas.

3. Penyemprotan disinfektan secara berkala.

4. Penggunaan handsanitizer sebelum kegiatan literasi atau membaca buku di pojok baca dan perpustakaan.

Sudah kita ketahui bahwa penerapan gerakan literasi sekolah di sekolah- sekolah yang telah menerapkannya akan menghasilkan dampak yang baik untuk siswa dan seluruh warga yang ada di sekolah. Salah satu dampak yang dapat dilihat adalah adanya penumbuhan minat baca pada siswa yang awalnya mereka hanya sedikit atau bahkan sama sekali tidak menyukai kegiatan membaca baik buku pelajaran ataupun non pelajaran.

Penanaman gemar membaca untuk siswa di SDN Rejomulyo 1 sudah ditanamkan sejak mereka berada di kelas yang paling bawah atau kelas 1 Sekolah Dasar sehingga ketika berada di kelas siswa sudah memiliki kebiasaan membaca buku setiap hari. Proses penanaman karakter gemar membaca diawali dengan kegiatan pembiasaan, yang mana kegiatan pembiasaan itu dilakukan secara konsisten dan terus menerus. Kegiatan pembiasaan di kelas $\mathrm{V}$ dilaksanakan melalui program yang diadakan oleh guru dalam rangka pelaksanaan Implementasi Gerakan Literasi Sekolah seperti halnya kegiatan 15 menit membaca sebelum kegiatan belajar dimuali, kunjungan wajib ke perpustakaan sekolah sesuai jadwal yang telah dibuat atau dapat juga berkunjung ke perpustakaan sekolah diluar jam kunjungan, membuat sebuah karya sesuai dengan 
kemampuan mereka, dan membaca buku-buku yang telah disediakan di pojok baca, dan masih banyak kegiatan lain yang dapat mereka lakukan sebagai bentuk penanaman karakter gemar membaca sejak dini.

Minat baca yang akhirnya menjadi kebiasaan gemar membaca merupakan kegiatan yang dilakukan dan telah menjadi kebiasaan dengan suka rela mengadakan beberapa waktu untuk membaca buku dan mencari informasi dibuku, internet, majalah, koran, serta media lain yang memunculkan suatu kebermanfaatan bagi diri sendiri. Kecakapan ini dimiliki seseorang agar dapat faham tentang isi yang ditulis dan mampu untuk menerapkannya kedalam praktek keseharian.

Berdasarkan data yang peneliti peroleh dan telah peneliti paparkan pada bab sebelumnya, maka bentuk minat baca serta keterampilan membaca yang dimiliki oleh Siswa Kelas V SDN Rejomulyo 1 setelah diterapkannya gerakan literasi sekolah adalah sebagai berikut:

1. Minat baca siswa dapat dilihat melalui keseharian siswa yang mana mereka lebih sering menggunakan waktu kosong atapun ketika istirahat mereka lebih memilih untuk berkunjung ke perpustakaan sekolah, atau mereka menempati pojok baca kelas dan mengambil buku bacaan sesuai dengan yang mereka inginkan.

2. Semakin baiknya minat baca yang tertanam pada diri siswa juga dapat dilihat melalui semakin hari semakin banyak pula yang mengunjungi perpustakaan sekolah, hal tersebut dapat diketahui melalui daftar hadir pengunjung perpustakaan yang telah disediakan oleh pihak sekolah.

3. Antusiasme siswa dalam mengikuti setiap kegiatan gerakan literasi sekolah dan juga banyaknya siswa yang mendapatkan juara saat mengikuti perlombaan yang di luar sekolah yang berhubungan dengan literasi juga merupakan bentuk karakter yang sudah tertanam pada diri siswa.

4. Keterampilan membaca di kelas atas:

a. Siswa kelas atas sudah dapat membaca dengan fasih dan dapat membaca dengan intonasi yang tepat sesuai dengan tanda titik (.) dan koma (,) yang ada atau bahkan ketika ada tanda baca yang lain, mereka sudah lebih dapat memahami dan mengintonasikan bacaan tersebut sesuai dengan tanda baca yang ada.

b. Siswa membaca buku cerita fiksi, nonfiksi, ataupun buku pelajaran, buku sejarah, ensiklopedia. Kemudian siswa menyampaikan cerita dengan efektif berdasarkan apa yang telah dibacanya. Biasanya ketika mereka berada di perpustakaan sekolah, siswa yang bercerita ulang maju ke atas panggung untuk bercerita ke teman-temannya

c. Siswa dapat menuliskan tanggapan atau kesan terhadap bacaan yang telah dibacanya dengan kalimat sederhana.

d. Membuat karya tulis yang lebih baik daripada siswa kelas bawah, biasanya mereka membuat karya tulis berupa puisi, ataupun cerita pendek.

e. Siswa kelas atas sudah bisa mengemukakan pendapat terkait dengan bacaan yang telah mereka baca. Ungkapan pendapat mereka sampaikan di depan teman-temannya, atau bisa juga mereka tuliskan di buku sesuai dengan apa yang diperintahkan oleh guru kelas.

Kendala Implementasi Gerakan Literasi Sekolah di Kelas V SDN Rejomulyo 1 tentunya berhubungan dengan kendala Implementasi Gerakan Literasi Sekolah di SDN Rejomulyo 1 secara keseluruhan, yang diantaranya adalah:

1. Ketersediaan dana merupakan faktor yang menjadi penghambat pelaksanaan gerakan literasi sekolah di SDN Rejomulyo 1. Sumber dana hanya mengandalkan dari dana BOS sehingga ketersediaan dana sangat terbatas. Dengan adanya sumber dana yang kurang bagus maka juga menghambat pemenuhan sarana dan prasarana yang layak sehingga pelaksanaan gerakan literasi tidak dapat berjalan dengan maksimal.

2. Seringkali ditemukan siswa yang malas membaca. Siswa lebih memilih untuk bermain bersama temannya saat waktu luang atau waktu istirahat. Mereka lebih memilih bersenang-senang daripada membaca buku. Hambatan ini dapat diatasi dengan strategi yang dipilih oleh guru. Guru harus memilih dan menggunakan strategi yang menarik untuk meningkatkan minat membaca anak. Diperlukan juga adanya inovasi dan kreasi baru yang harus dilakukan pada buku-buku di sudut baca kelas. Cara tersebut dapat dilakukan dengan menambah buku bacaan baru yang bergambar. Tujuan dari inovasi ini adalah karena siswa akan lebih tertarik saat melihat buku yang dilengkapi dengan gambar. Tidak jarang ditemukan siswa yang berebut buku bacaan dengan temannya, ataupun siswa yang membaca buku 
padahal ia sudah membaca buku yang sama secara berulang-ulang. Solusi dari permasalahan tersebut yaitu dengan cara selalu memberikan dorongan kepada siswa untuk membaca, atau dapat juga dengan memberikan tugas rangkuman kepada siswa. Dengan begitu, mau ataupun tidak siswa harus tetap membaca.

3. Kurangnya variasi pada buku pengayaan yang berada di perpustakaan juga menjadi kendala dalam melaksanakan gerakan literasi sekolah. Hal ini dapat diatasi dengan cara pihak layanan perpustakaan untuk menambahkan variasi pada buku pengayaan. Menambah variasi pada buku pengayaan dapat dilakukan dengan memilih buku pengayaan yang sebelumnya belum pernah disediakan di perpustakaan sekolah. Selain itu variasi tersebut juga harus diimbangi dengan melakukan refresh pada sumber pustaka di perpustakaan sekolah. Refresh sumber pustaka di perpustakaan sekolah harus dilakukan secara berkala seperti 2 bulan sekali.

4. Kurang menariknya strategi yang digunakan untuk mengingkatkan pemahaman bacaan siswa. Solusinya yaitu dengan cara guru harus mencari strategi menarik baru untuk membuat siswa lebih tertarik membaca. Dengan begitu, siswa dapat lebih mudah untuk menganalisis bacaan yang telah ia baca sebelumnya. Salah satu contoh strategi menarik yang dapat digunakan guru adalah drama atau bermain peran. Melalui strategi drama (bermain peran), siswa akan secara langsung mempraktikkan dan bermain dengan emosinya. Hal tersebut dapat berfungsi untuk pemahaman siswa. Siswa akan lebih mudah memahami alur cerita dan makna drama tersebut. Hal itu akan memudahkan siswa untuk bisa menjawab pertanyaan dan menganalisis makna/inti dari cerita.

5. Tingkat kesadaran guru terhadap pentingnya kegiatan literasi berpengaruh pada dari pelaksanaan tanggung jawab mereka dalam melaksanakan program-program gerakan literasi sekolah. Sebagian guru pada kelas tinggi masih kurang disiplin dalam melaksanakan kegiatan membaca 15 menit sebelum pelajaran dimulai.Kepala sekolah dapat mendisiplinkan guru dengan cara mengeluarkan kebijakan yang menunjukkan bahwa program literasi merupakan program prioritas sekolah. Sebagian guru tampak masih jarang membaca buku ketika mereka memiliki waktu luang. Kondisi yang berlawanan dengan kebiasaan membaca akan memunculkan perasaan negatif yang membuat peserta didik beranggapan bahwa membaca itu adalah kegiatan yang tidak penting.

6. Sejak adanya Pandemi Covid-19 praktis kegiatan literasi sekolah kurang dapat berjalan dengan baik. Meskipun pihak sekolah telah berupaya melakukan kegiatan literasi secara online namun banyak siswa yang lebih banyak mengisi kegiatan di rumah dengan bermain game daripada menggunakan smartphonenya untuk belajar apalagi membaca e-book.

Sebagai kegiatan baru, tentunya Gerakan Literasi Sekolah dapat dilaksanakan sesuai harapan apabila mendapat dukungan dari berbagai pihak terkait. Faktor-faktor pendukung pelaksanaan Gerakan Literasi Sekolah di SDN Rejomulyo 1 adalah sebagai berikut:

1. Komitmen Kepala SDN Rejomulyo 1 untuk menerapkan Permendikbud Nomor 23 Tahun 2015 tentang Penumbuhan Budi Pekerti yang melahirkan program Gerakan Literasi Sekolah. Suatu kegiatan akan terlaksana dengan baik ketika pimpinan tertinggi di institusi tersebut memiliki komitmen untuk melaksanakannya. Faktor Kepala Sekolah sebagai pendukung kegiatan Gerakan Literasi Sekolah ini sejalan dengan temuan penelitian pada bab sebelumnya.

2. Guru, siswa, dan wali murid mendukung terlaksananya Implementasi Gerakan Literasi Sekolah di SDN Rejomulyo 1. Mereka melaksanakan Gerakan Literasi sesuai jadwal yang dibuat sekolah. Siswa dengan sukarela membawa buku dari rumah, bwekunjung ke perpustakaan, membaca di pojok baca kelas. Selain itu guru-guru turut membaca buku cerita yang tersedia di kelasnya agar dapat membantu siswa memahami cerita yang dibacanya. Orang tua siswa pun turun berperan dalam mendesain pojok baca di kelas.

3. Sejak adanya Gerakan Literasi Sekolah, siswa sangat antusias dalam berpartisipasi mengikuti setiap kegiatan. Dengan antusias siswa yang tinggi dalam membaca buku, maka minat baca siswa juga turut meningkat. Untuk meningkatkan minat baca memang tidak mudah, diperlukan waktu yang panjang serta dukungan dan berbagai pihak sehingga diharapkan menjadi budaya pada diri mereka. Pada akhirnya Gerakan Literasi Sekolah ini menjadi penting karena pembelajaran sekarang adalah pembelajaran abad 21 yang bertujuan agar siswa dapat berfikir kritis, berkolaborasi, komunikatif, dan kreatif. 


\section{SIMPULAN}

Berdasarkan deskripsi dan pembahasan dalam penelitian ini maka dapat diambil simpulan sebagai berikut.

1. Yang melatarbelakangi Implementasi Gerakan Literasi Sekolah di SDN Rejomulyo 1 adalah adanya penurunan minat baca siswa ataupun kegiatan literasi yang lain seperti mendengarkan, bercerita, juga dalam mempelajari ilmu pengetahuan yang lainnya. Oleh sebab itu, pihak sekolah berinisiatif untuk menerapkan gerakan literasi sekolah di SDN Rejomulyo 1 dengan dukungan dari berbagai pihak.

2. Di kelas V SDN Rejomulyo 1 selain melalui kunjungan perpustakaan yang menjadi sarana literasi, Implementasi Gerakan Literasi Sekolah dilakukan melalui pengembangan sudut baca kelas.

3. Minat baca siswa dapat dilihat melalui keseharian siswa yang mana mereka lebih sering menggunakan waktu kosong atapun ketika istirahat mereka lebih memilih untuk berkunjung ke perpustakaan sekolah, atau mereka menempati pojok baca kelas dan mengambil buku bacaan sesuai dengan yang mereka inginkan.

4. Kendala Implementasi Gerakan Literasi Sekolah di Kelas V SDN Rejomulyo 1 tentunya berhubungan dengan kendala Implementasi Gerakan Literasi Sekolah di SDN Rejomulyo 1 secara keseluruhan.

a. Sumber dana hanya mengandalkan dari dana BOS sehingga ketersediaan dana sangat terbatas.

b. Seringkali ditemukan siswa yang malas membaca. Siswa lebih memilih untuk bermain bersama temannya saat waktu luang atau waktu istirahat. Mereka lebih memilih bersenang-senang daripada membaca buku.

c. Kurangnya variasi pada buku pengayaan yang berada di perpustakaan.

d. Kurang menariknya strategi yang digunakan untuk mengingkatkan pemahaman bacaan siswa.

e. Tingkat kesadaran guru terhadap pentingnya kegiatan literasi masih kurang.

f. Sejak adanya Pandemi Covid-19 praktis kegiatan literasi sekolah kurang dapat berjalan dengan baik, walaupun sebenarnya pihak sekolah telah berupaya melakukan kegiatan literasi sekolah secara online.

5. Faktor-faktor pendukung pelaksanaan Gerakan Literasi Sekolah di SDN Rejomulyo 1 adalah sebagai berikut:

a. Komitmen Kepala SDN Rejomulyo 1 untuk menerapkan Permendikbud Nomor 23 Tahun 2015 tentang Penumbuhan Budi Pekerti yang melahirkan program Gerakan Literasi Sekolah.

b. Guru, siswa, dan wali murid mendukung terlaksananya Implementasi Gerakan Literasi Sekolah di SDN Rejomulyo 1.

c. Siswa sangat antusias dalam berpartisipasi mengikuti setiap kegiatan literasi sekolah.

Implementasi Gerakan Literasi Sekolah di SDN Rejomulyo 1 telah meningkatkan minat baca siswa di kelas V dan seluruh warga sekolah SDN Rejomulyo 1. Meskipun terjadinya Pandemi Covid-19 telah menghambat program-program literasi yang dijalankan, namun pihak sekolah tetap berupaya melaksanakan Gerakan Literasi Sekolah secara online menggunakan e-book atau bentuk literasi yang lain. Hal ini berdampak positif meskipun tidak keseluruhan siswa dapat mengikuti dengan baik, terbukti sebagian besar siswa sangat antusias mengikuti kembali Gerakan Literasi Sekolah ketika sekolah telah melaksanakan Pembelajaran Tatap Muka Terbatas mulai pertengahan semester ganjil tahun pelajaran 2021/2022.

\section{DAFTAR PUSTAKA}

Antasari, Indah Wijaya. (2017). Implementasi Gerakan Literasi Sekolah Tahap Pembiasaan di MI Muhammadiyah Gandatapa Sumbang Banyumas. Jurnal, Vol.9, No.1. https://jurnal.arraniry.ac.id/index.php/libria/article/view/1680

Moleong, J. Lexi. (2009). Metodologi Penelitian Kualitatif. Bandung: PT. Remaja Rosdakarya.

Naelasari, Desy. (2020). Implementasi Gerakan Literasi Sekolah Dalam Meningkatkan Budi Pekerti Siswa di Smk Nusantara Jombang. Jurnal Ilmuna vol.2 no. 2 September 2020 
Rahmawati. (2007). Model Pendeteksian Manajemen Laba pada Industri Perbankan Publik di Indonesia dan Pengaruhnya terhadap Kinerja Perbankan. Jurnal Akuntansi dan Manajemen, XVIII (1), hal. 23-34.

Suwandi, S., (2019). Tantangan Mewujudkan Pembelajaran Bahasa dan Sastra Indonesia yang Efektif di Era Revolusi Industri 4.0. Jurnal Universitas Sebelas Maret. 1-20.

Soleh, Dwi Rohman. (2016). Etika Jawa Dalam Novel La Grande Borne Karya N.H. Dini. Widyabastra 4(2) pp. 121-132.

Soleh, Dwi Rohman. Herman J. Waluyo. Setya Yuwana Sudikan. Nugraheni Eko Wardani. (2017). Model Development of Drama Study Employing Local Art for Students Of LPTK. Prosiding Internasional FINALISET 1(3) pp. 19-28.

Soleh, Dwi Rohman. (2020). Pembelajaran Sastra Lisan Berbasis Soft Skill dalam Penerapan Literasi Digital. Prosiding Seminar Daring Nasional: Pengembangan Kurikulum Merdeka Belajar. Pp. 160-166.

Wiedarti, dkk. (2016). Desain Induk Gerakan Literasi Sekolah. Jakarta: Direktorat Jenderal Pendidikan Dasar dan Menengah Kementerian Pendidikan dan Kebudayaan.

Yunus Abidin, dkk., 2017. Pembelajaran literasi: strategi meningkatkan kemampuan literasi matematika, sains, membaca, dan menulis. Jakarta: Bumi Aksara. 